\title{
Preservation of Neisseria gonorrhoeae by the gelatin-disc method
}

\author{
SHIRO YAMAI, YASUSHI OBARA, TAKAYASU NIKKAWA, YUKO SHIMODA, \\ AND YASUSHI MIYAMOTO \\ From the Department of Bacteriology and Pathology, Kanagawa Prefectural Public Health Laboratory, \\ Yokohama, Japan
}

SUMMARY Studies of Neisseria gonorrhoeae are difficult to perform because of the organism's poor survival in vitro. To solve this problem we tried to preserve the organism by a gelatin-disc method. The rate of survival and changes of variations in some biochemical properties of eight strains of $N$. gonorrhoeae were followed for three years. These studies proved that preservation was satisfactory with only a 1/10 reduction of the living cells. Another trial showed that the organism survived for over six months after being frozen at $-20^{\circ} \mathrm{C}$. The colonial types, agglutination against red cells from rabbit and guinea pig, and antibiotic susceptibility to penicillin, chloramphenicol, tetracycline, kanamycin, and streptomycin did not change after three years' preservation.

\section{Introduction}

Kellogg et al. $(1963,1968)$ demonstrated a close correlation between colonial type and pathogenicity of Neisseria gonorrhoeae. Later Swanson et al. (1971) detected pili in pathogenic $\mathrm{T} 1$ and $\mathrm{T} 2$ colonies. Correlation between pathogenicity and colonial types and pili has also been reported by several investigators (Thongthai and Sawyer, 1973; Punsalang and Sawyer, 1973; Bumgarner and Finkelstein, 1973). Difficulties have been experienced in such studies, however, because the organism can only survive for a short time and mutation readily occurs with successive transfer of the subculture with loss of pathogenicity.

The most effective method for preserving $N$. gonorrhoeae now in common use is lyophilisation. Its application for a large number of strains, however, is complex and impossible in a small laboratory. We, therefore, attempted and successfully improved the preservation method by using desiccated gelatin, which was originally developed and effectively applied to the species of Enterobacteriaceae by Stamp (1947).

\footnotetext{
Address for reprints: Dr Y. Miyamoto, Department of Bacteriology and Pathology, Kanagawa Prefectural Public Health Laboratory, 52 Nakaocho Asahi-Ku, Yokohama, Japan

Received for publication 5 September 1978
}

\section{Material and methods}

MEDIA

Transgrow medium (Martin and Lester, 1971) for primary isolation and Difco GC medium base with $2 \%$ defined supplement (GCB-2DS) (Kellogg et al., 1963) for confirmation of colonial-type and cell count were used.

GONOCOCCAL STRAIN AND COLONIAL TYPE Eight fresh isolates of $N$. gonorrhoeae isolated in our laboratory in 1973-74 were used; strains 48-14 and 48-17 were isolated in 1973 from women with acute cervicitis. Strains 49-2, 49-13, 49-48, 49-52, and 49-60 were all isolated from men with acute urethritis and strain 49-8 was isolated from a woman with chronic cervicitis. The last six strains were isolated in 1974. They were identified by Gram staining, oxidase reaction, and carbohydrate fermentation. The colonial type was determined according to the definition of Kellogg et al. (1963) with the colony grown on GCB-2DS medium.

\section{REAGENTS}

Reagents for preparing gelatin-disc were prepared as follows:

(1) Distilled water solution of Bacto dextrose $(5 \%)$ with Bacto skim milk $(3 \%)$ and decolouring carbon $(0.6 \%$, Norit, Extra, NV 
Norit-Vereenigung) was sterilised at $110^{\circ} \mathrm{C}$ for 10 minutes and stored in a refrigerator (solution A).

(2) Distilled water solution of sodium L-ascorbate $(0.5 \%$, Wako) was sterilised by filtration through a millipore filter and stored at $-20^{\circ} \mathrm{C}$ (solution $\mathrm{B}$ ).

(3) Distilled water solution of Bacto gelatin $(20 \%)$ was sterilised at $121^{\circ} \mathrm{C}$ for 15 minutes and stored in a refrigerator (solution $\mathbf{C}$ ).

As an antioxidant L-ascorbic acid, instead of sodium L-ascorbate, was also used for comparison, but the results were not promising.

\section{INSTRUMENTS AND MATERIALS FOR}

PREPARING DISCS

Circular filter papers $7 \mathrm{~cm}$ in diameter (Toyo no. 2) were soaked in melted solid paraffin (melting point $56-58^{\circ} \mathrm{C}$ ) (Wako) heated at $140^{\circ} \mathrm{C}$ for five minutes over a gas burner, removed with sterile forceps, and placed individually in a sterilised Petri dish, which was used as the receiver for droplets of cell suspension.

A glass desiccator with $500 \mathrm{~g}$ silica gel was used for drying; a glass cylinder with a wide opening containing 200 to $300 \mathrm{~g}$ of phosphorus pentoxide $\left(\mathrm{P}_{2} \mathrm{O}_{5}\right)$ was placed in the dessicator.

A sterile capillary pipette giving a $0.03-\mathrm{ml}$ droplet was used for dropping the cell suspension.

A 5-ml small vial with a wide opening, containing silica gel, was closed with a cotton plug and used for the storage of the desiccated gelatin discs containing the organisms.

\section{PREPARATION OF GELATIN DISC}

Each of the eight strains was inoculated on to two to three GCB-2DS agar plates and incubated at $35^{\circ} \mathrm{C}$ for 18 to 20 hours in a candle extinction jar. The organisms were collected to prepare a homogeneous suspension of $10^{10}$ cells $/ \mathrm{ml}$ of solution $A$ previously warmed to $35^{\circ} \mathrm{C}$ and stirred for 30 seconds with a vibrator. To this suspension were added similarly warmed $0.2 \mathrm{ml}$ of solution $B$ and $1 \mathrm{ml}$ of solution $\mathrm{C}$, which had been previously dissolved by heating and kept at $35^{\circ} \mathrm{C}$; the suspension was stirred again for 30 seconds. The mixed suspension thus prepared was delivered dropwise with the capillary pipette on to the paraffin-soaked filter paper in the Petri dish. This Petri dish, with its cover slightly open, was placed in the desiccator and dried at room temperature under reduced atmospheric pressure $(20 \mathrm{~mm} \mathrm{Hg}[2.7 \mathrm{kPa}])$ with a vacuum pump. After four to six hours the hydrated portion near the surface of the $\mathrm{P}_{2} \mathrm{O}_{5}$ was removed to help further dehydration. It was then left overnight under a reduced pressure of $10 \mathrm{~mm}$
$\mathrm{Hg}(1.35 \mathrm{kPa})$. After 24 hours the droplet had completely dried and changed into a thin and flat circular gelatin disc, which either came off the filter paper spontaneously or was lifted off with forceps. The discs of each strain were collected and put in the small vial, which was then tightly sealed and stored at $-20^{\circ} \mathrm{C}$.

\section{VIABLE CELL COUNT}

The quantitative cell count was performed on strains $48-14$ and 48-17 immediately before and after drying and every month of each year thereafter. In addition, a pool of five discs from each strain was put into a small test tube, dissolved, and resuspended with $1 \mathrm{ml}$ of heart infusion broth (Eiken) by heating at $35^{\circ} \mathrm{C}$. After a series of tenfold dilutions of this original suspension had been prepared, each $0.1 \mathrm{ml}$ of the dilution was streaked on a GC-2DS agar plate and then incubated at $35^{\circ} \mathrm{C}$ in a candle extinction jar for 24 hours. The number of colony-forming units (cfu) was thus counted, giving the number of viable cells per disc. In addition, six strains (49-2, 49-8, 49-13, 49-48, 49-52, and 49-60), were subjected to a qualitative study - that is, one disc from each strain was dissolved in $0.2 \mathrm{ml}$ of heart infusion broth, one loopful of which was streaked on to a GCB-2DS agar and incubated at $35^{\circ} \mathrm{C}$ for 24 to 48 hours to determine colony-forming capacity.

\section{STORAGE TEMPERATURE}

To examine the effect of temperature on the survival of cells embedded in the gelatin disc, discs from the same batch were stored at different temperatures (that is, at $30^{\circ} \mathrm{C}, 5^{\circ} \mathrm{C}$, and $-20^{\circ} \mathrm{C}$ ) and the change in cfu was followed with estimations at weekly intervals for six weeks and finally at 24 weeks.

\section{ANTIBIOTIC SUSCEPTIBILITY TESTING}

The method of Martin et al. (1970) was used for testing antibiotic susceptibility to penicillin, chloramphenicol, tetracycline, kanamycin, and streptomycin.

\section{HAEMAGGLUTINATION REACTION}

Red cells from rabbit and guinea pig were used according to the method of Punsalang and Sawyer (1973).

\section{Results}

All the eight strains stored survived three years' preservation. The decline of viable cells of strains 48-14 and 48-17 are shown in Figure 1. Despite a 


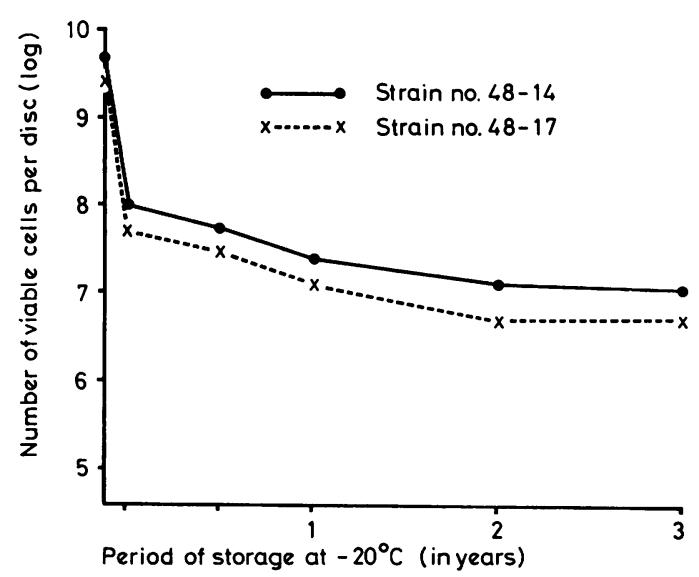

Fig. 1 Survival of Neisseria gonorrhoeae in gelatin discs

rapid decline of viable cells up to $10^{-2}$ of the initial suspension immediately after desiccation, the decline was less thereafter and dropped within the range of $10^{-1}$ of the initial suspension. The decline of viable cells, therefore, throughout the three-year preservation period was within the order of $10^{-3}$ of the initial suspension.

As shown in Table 1, colonial types were also maintained well after three years' preservation with only a slight decrease in frequency of appearance of the types 1 and 2 of some strains.

Tests of the effect of temperature on the viability of the cells embedded in gelatin disc showed that they were least affected when stored at $-20^{\circ} \mathrm{C}$ even after six months, whereas no colony was formed after five to six weeks when stored at $30^{\circ} \mathrm{C}$. The decline of viable cells after six months was within the order of $10^{-3}$ at $-20^{\circ} \mathrm{C}$ and $10^{-4}$ at $5^{\circ} \mathrm{C}$.

As regards the effect of antioxidants added to the mixed suspension, the decrease in viable cell count

Table 1 Percentage of colonial types of original and recovered cultures

\begin{tabular}{|c|c|c|c|c|}
\hline \multirow{3}{*}{ Strain no. } & \multicolumn{4}{|c|}{$\%$ of colonial types } \\
\hline & \multicolumn{2}{|c|}{ Original culture } & \multicolumn{2}{|c|}{$\begin{array}{l}\text { Recovered culture (after } \\
3 \text { years) }\end{array}$} \\
\hline & Type 1-2 & Type 3-4 & Type 1-2 & Type 3-4 \\
\hline $\begin{array}{l}48-14 \\
48-17 \\
49-2 \\
49-8 \\
49-13 \\
49-48 \\
49-52 \\
49-60\end{array}$ & $\begin{array}{l}10 \\
10 \\
90 \\
90 \\
90 \\
90 \\
90 \\
90\end{array}$ & $\begin{array}{l}90 \\
90 \\
10 \\
10 \\
10 \\
10 \\
10 \\
10\end{array}$ & $\begin{array}{l}10 \\
10 \\
90 \\
80 \\
90 \\
70 \\
80 \\
90\end{array}$ & $\begin{array}{l}90 \\
90 \\
10 \\
20 \\
10 \\
30 \\
20 \\
10\end{array}$ \\
\hline
\end{tabular}

immediately after freezing was less with sodium L-ascorbate than with L-ascorbic acid-that is, the former decrease was $10^{-2}$ whereas the latter was $10^{-3}$ of the initial suspension. The decrease while freezing was also less in the case of sodium L-ascorbate, the minimum effect being with the addition of $0.05 \mathrm{ml} / \mathrm{ml}$ giving a final concentration of $0.5 \%$, and it was, therefore, appropriate for use. These effects are shown in Figure 2.

As shown in Table 2, no change was observed in the antibiotic susceptibility of any strains which were either highly sensitive or relatively resistant to penicillin or sensitive or resistant to streptomycin. They all agreed within a one-step difference of the gradation of minimum inhibitory concentration (MIC) after three years' preservation. Similarly, no change was observed in the susceptibility to chloramphenicol, tetracycline, and kanamycin.

No changes were seen in haemagglutination reaction when blood cells of either rabbit or guinea pig were used.

\section{Comment and conclusions}

Lyophilisation has been regarded as the most effective method for preserving strains of $N$. gonorrhoeae. Convenient methods have also been reported by Pospisil and Kabátová (1969), Sparling (1966), Thomas et al. (1973), Ofek et al. (1974),

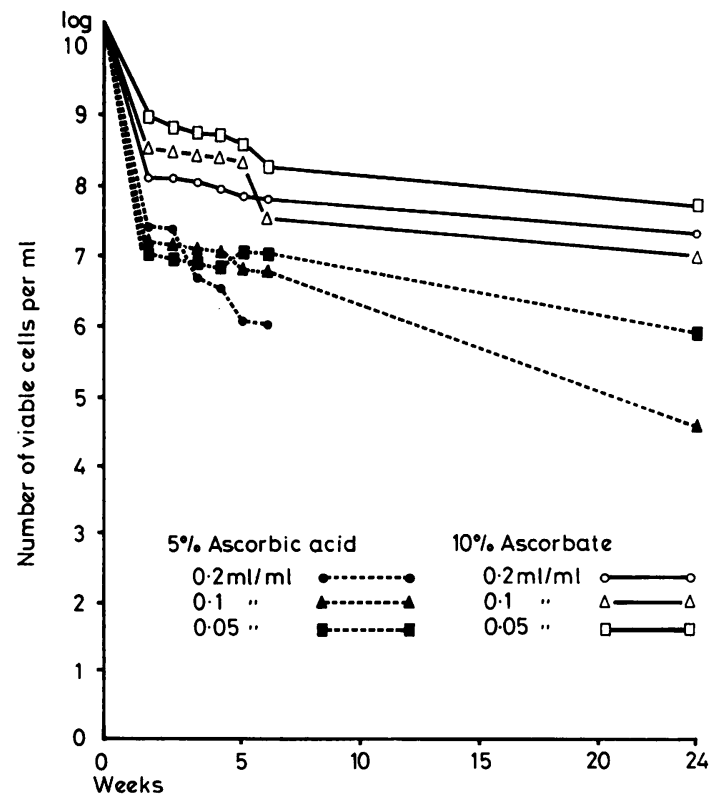

Fig. 2 Effect of antioxidants (sodium $L$-ascorbate and $L$-ascorbic acid) on survival of Neisseria gonorrhoeae during 24 weeks of preservation by freezing at $-20^{\circ} \mathrm{C}$ 
Table 2 Drug susceptibility of strains of Neisseria gonorrhoeae before and after storage for three years

\begin{tabular}{|c|c|c|c|c|c|c|}
\hline \multirow[b]{2}{*}{$\begin{array}{l}\text { Strain } \\
\text { no. }\end{array}$} & \multirow[b]{2}{*}{ Year } & \multicolumn{5}{|c|}{ Drug susceptibility (MIC) } \\
\hline & & $\begin{array}{l}P C \\
(\mu g / m l)\end{array}$ & $\begin{array}{l}S M \\
(\mu g / m l)\end{array}$ & $\begin{array}{l}C P \\
(\mu g / m l)\end{array}$ & $\begin{array}{l}T C \\
(\mu g / m l)\end{array}$ & $\begin{array}{l}K M \\
(\mu g / m l)\end{array}$ \\
\hline \multirow[t]{2}{*}{$48-14$} & 1974 & 0.03 & $6 \cdot 3$ & 4 & 1 & 8 \\
\hline & 1977 & 0.02 & $12 \cdot 5$ & 4 & 1 & 4 \\
\hline \multirow[t]{2}{*}{$48-17$} & 1974 & 1 & $\geqslant 200$ & 2 & 1 & 8 \\
\hline & 1977 & 0.05 & $\geqslant 200$ & 2 & 1 & 4 \\
\hline \multirow[t]{2}{*}{$49-2$} & 1974 & 2 & $\geqslant 200$ & 8 & 4 & 16 \\
\hline & 1977 & 1 & $\geqslant 200$ & 8 & 4 & 16 \\
\hline \multirow[t]{2}{*}{$49-8$} & 1974 & 0.02 & $6 \cdot 3$ & 4 & 1 & 8 \\
\hline & 1977 & 0.03 & $6 \cdot 3$ & 4 & 1 & 8 \\
\hline \multirow[t]{2}{*}{$49-13$} & 1974 & 1 & $\geqslant 200$ & 4 & 2 & 8 \\
\hline & 1977 & 1 & $\geqslant 200$ & 4 & 4 & 16 \\
\hline \multirow[t]{2}{*}{$49-48$} & 1974 & 1 & $\geqslant 200$ & 8 & 4 & 8 \\
\hline & 1977 & 1 & $\geqslant 200$ & 8 & 4 & 8 \\
\hline \multirow[t]{2}{*}{$49-52$} & 1974 & 1 & $\geqslant 200$ & 2 & 0.5 & 8 \\
\hline & 1977 & 1 & $\geqslant 200$ & 2 & 1 & 8 \\
\hline \multirow[t]{2}{*}{$49-60$} & 1974 & 1 & $\geqslant 200$ & 8 & 2 & 8 \\
\hline & 1977 & 2 & $\geqslant 200$ & 8 & 2 & 16 \\
\hline
\end{tabular}

PC penicillin, SM streptomycin, CP chloramphenicol, TC tetracycline, KM kanamycin

and Apicella (1974). These lyophilisation or freezing methods, however, require expensive instruments and considerable space is occupied by the ampoules or tubes, which limits the number of strains to be stored.

In order to preserve strains of $N$. gonorrhoeae we attempted to apply and modify Stamp's (1947) classic simple method of preserving bacteria embedded in dried gelatin. For this purpose we used a lyophilisation medium, which we have routinely used for Vibrio cholerae strains, to which gelatin was added. The experiment resulted in success and $N$. gonorrhoeae was stored and kept alive by our gelatin-disc method for over three years. The properties which the organisms possessed at the time of fresh isolation were retained. Gelatin-mixed bacterial suspensions used for preparing the gelatin discs could also be stored in a viable state without desiccation by being frozen at $-20^{\circ} \mathrm{C}$ for over six months.

Since our method is simple and requires neither expensive instruments nor large storage space, it is applicable in a small laboratory. The preservation of numerous strains under the same conditions in a compact state with many but small discs enables us to repeat our experiment and makes a long-term experiment feasible under the same conditions. Since the organism can also survive in gelatin discs at room temperature for several weeks, the method is simple and convenient for transportation.
When gelatin discs are prepared, the following should be observed:

(1) Large amounts of a young culture incubated for 18 to 20 hours should be used.

(2) A dense cell suspension, such as $10^{10}$ cells per $\mathrm{ml}$, should be prepared.

(3) Desiccation should be completed within a short time. The hydrated portion of $\mathrm{P}_{2} \mathrm{O}_{5}$ should, therefore, be removed and replaced with fresh $\mathrm{P}_{2} \mathrm{O}_{5}$ during the drying process.

(4) Once desiccation is complete, the discs should be stored in a small vial with silica gel-that is, under dehydrated conditions at $5^{\circ} \mathrm{C}$ or $-20^{\circ} \mathrm{C}$.

\section{References}

Apicella, M. A. (1974). Antigenically distinct population of Neisseria gonorrhoeae: Isolation and characterization of the responsible determinants. Journal of Infectious Diseases, 130, 619-625.

Bumgarner, L. R., and Finkelstein, R. A. (1973). Pathogenesis and immunology of experimental gonococcal infection: Virulence of colony types of Neisseria gonorrhoeae for chicken embryos. Infection and Immunity, 8, 919-924.

Kellogg, D. S., jun., Peacock, W. L., jun., Deacon, W. E., Brown, L., and Pirkle, C. I. (1963). Neisseria gonorrhoeae. 1. Virulence genetically linked to clonal variation. Journal of Bacteriology, 85, 1274-1279.

Kellogg, D. S., jun., Cohen, I. R., Norins, L. C., Schroeter, A. L., and Reising, G. (1968). Colonial variation and pathogenicity during 35 months in vitro. Journal of Bacteriology, 96, 596-605.

Martin, J. E., jun., Lester, A., Price, E. V., and Schamale, J. (1970). Comparative study of gonococcal susceptibility to penicillin in the United States, 1955-1969. Journal of Infectious Diseases, 122, 459-461.

Martin, J. E., jun., and Lester, A. (1971). Transgrow. A medium for transport and growth of $N$. gonorrhoeae and $N$. meningitidis. HSMHA Health Report, 86, 30-33.

Ofek, I., Beachey, E. H., and Bisno, A. L. (1974). Resistance of Neisseria gonorrhoeae to phagocytosis: Relationship to colonial morphology and surface pili. Journal of Infectious Diseases, 129, 310-316.

Punsalang, A. P., jun., and Sawyer, W. D. (1973). Role of pili in the virulence of Neisseria gonorrhoeae. Infection and Immunity, 8, 255-263.

Pospisil, L., and Kábatová, A. (1969). Einfluss der Temperatur auf das Überleben von Neisseria gonorrhoeae in Transportmedien nach Roiron und Stuart. Zentralblatt für Bacteriologie, Parasitenkunde, Infektionskranakheiten und Hygiene, 211, 205-208.

Swanson, J., Kraus, S. J., and Gotschlich, E. C. (1971). Studies on gonococcus infection. 1. Pili and zones of adhesion: their relation to gonococcal growth patterns. Journal of Experimental Medicine, 134, 886-906.

Stamp, L. (1947). The preservation of bacteria by drying. Journal of General Microbiology, 1, 251-265.

Sparling, P. F. (1966). Genetic transformation of Neisseria gonorrhoeae to streptomycin resistance. Journal of Bacteriology, 92, 1364-1371.

Thongthai, C., and Sawyer, W. D. (1973). Studies on virulence of Neisseria gonorrhoeae. 1. Relation of colonial morphology and resistance to phagocytosis by polymorphonuclear leukocytes. Infection and Immunity, 7, 373-379.

Thomas, D. W., Hill, J. C., and Tyeryer, F. J., jun. (1973). Gonococci with phagocytic leukocytes from men and mice. Infection and Immunity, 8, 98-104. 